\title{
Author Correction: Inhibiting amyloid- $\beta$ cytotoxicity through its interaction with the cell surface receptor LilrB2 by structure-based design
}

Qin Cao (D), Woo Shik Shin, Henry Chan, Celine K. Vuong, Bethany Dubois, Binsen Li, Kevin A. Murray, Michael R. Sawaya (D), Juli Feigon, Douglas L. Black, David S. Eisenberg (D) and Lin Jiang (D)

Correction to: Nature Chemistry https://doi.org/10.1038/s41557-018-0147-z (2018), published online 8 October 2018.

In the version of this Article originally published online, the upper right panel of Fig. 5a was mistakenly a repeat of the lower right panel. This has now been corrected in all versions of the Article.

Published online: 12 November 2018

https://doi.org/10.1038/s41557-018-0182-9

Original

a LilrB2-mRFP + Vehicle

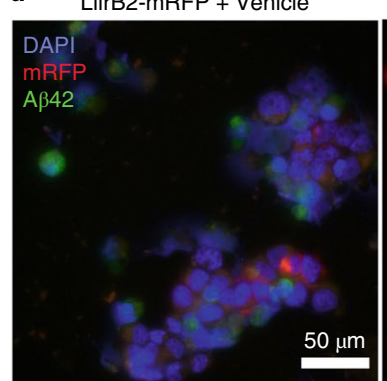

mRFP + Vehicle

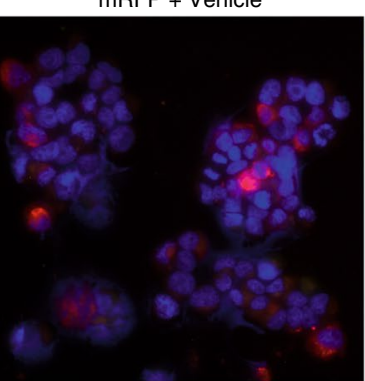

LilrB2-mRFP + ALI4

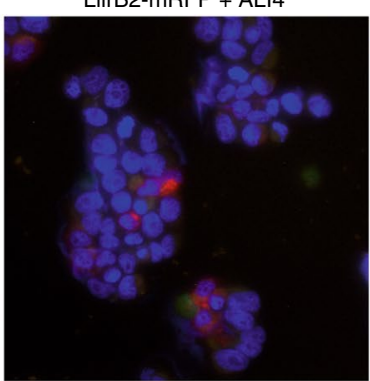

LilrB2-mRFP + ALI5

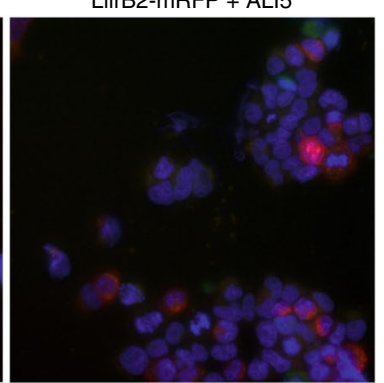

Corrected

a

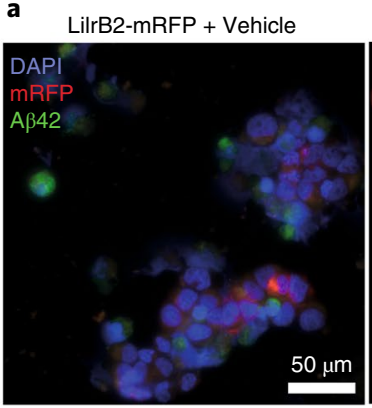

$\mathrm{mRFP}+$ Vehicle

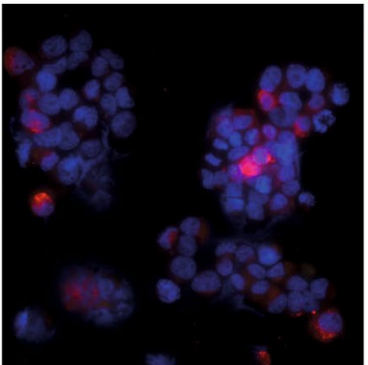

LilrB2-mRFP + ALI4

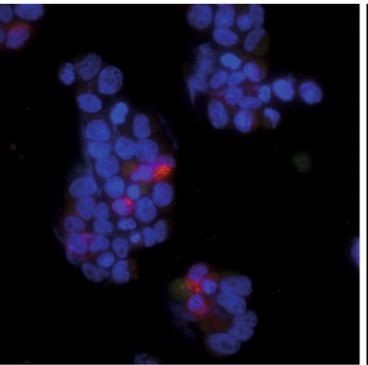

LilrB2-mRFP + ALI5

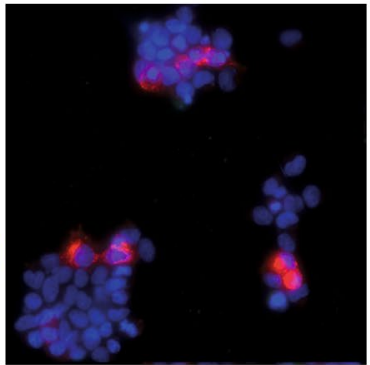

Fig. 5a | Original and corrected upper right panel. 